\title{
Nitrogen and potassium in the cultivation of Piatã grass in Brazilian Cerrado soil
}

\author{
Léa P. V. X. C. de Morais ${ }^{1}$, Edna M. Bonfim-Silva ${ }^{2}$, Adriano B. Pacheco², \\ Joadil G. de Abreu ${ }^{1}$, Tonny J. A. da Silva ${ }^{2} \&$ Analy C. Polizel ${ }^{2}$ \\ ${ }^{1}$ Universidade Federal de Mato Grosso/Faculdade de Agronomia e Zootecnia. Cuiabá, MT. E-mail: lea.morais@cnp.ifmt.edu.br; joadil@terra.com.br
${ }^{2}$ Universidade Federal de Mato Grosso/Instituto de Ciências Agrárias e Tecnológicas. Rondonópolis, MT. E-mail: embonfim@hotmail.com (Corresponding
author); ad.pacheco@hotmail.com; tonnyjasilva@hotmail.com; analy@ufmt.br
}

\section{Key words:}

Brachiaria brizantha nitrogen content potassium content $\mathrm{N}: \mathrm{K}$ ratio in plants

\begin{abstract}
A B S T R A C T
This study aimed to evaluate the production and mineral nutrition of Piatã grass as a function of nitrogen and potassium fertilization in Oxisol collected in the Cerrado. The experiment was carried out in a greenhouse, the experimental design was completely randomized, in a $5 \times 5$ factorial scheme, corresponding to five nitrogen doses $(0,100,200,300$ and 400 $\mathrm{mg} \mathrm{dm}{ }^{-3}$ of $\left.\mathrm{N}\right)$ and five potassium doses $\left(0,90,180,270\right.$ and $360 \mathrm{mg} \mathrm{dm}^{-3}$ of $\left.\mathrm{K}_{2} \mathrm{O}\right)$, with four replicates. Three cuts of the shoots were performed every 30 days. Chlorophyll index, dry mass of shoots and roots, and nitrogen and potassium contents in the leaves were evaluated. The dry mass of shoots showed interaction between nitrogen and potassium in the three cuts; in the second and third cuts, it had maximum production at the nitrogen and potassium doses of 254 and $158 \mathrm{mg} \mathrm{dm}^{-3}$, in the second, and 250 and $306 \mathrm{mg} \mathrm{dm}^{-3}$ in the third, respectively. The nitrogen and potassium contents are influenced as a function of nitrogen and potassium fertilization isolated by factor. The nitrogen and potassium ratio in the Piatã grass crop was around 1:1.
\end{abstract}

\section{Palavras-chave: Brachiaria brizantha concentração de nitrogênio concentração de potássio relação $\mathrm{N}: \mathrm{K}$ nas plantas}

\section{Nitrogênio e potássio no cultivo do capim-piatã em solo do Cerrado brasileiro}

\begin{abstract}
R E S U M O
Objetivou-se avaliar a produção e a nutrição mineral do capim piatã em função da adubação nitrogenada e potássica em Latossolo Vermelho coletado no Cerrado. Realizouse o experimento em casa de vegetação, o delineamento experimental foi inteiramente casualizado em esquema fatorial de 5 x 5 sendo cinco doses de nitrogênio $(0,100,200$, 300 e $400 \mathrm{mg} \mathrm{dm}^{-3}$ ) e cinco doses de potássio $\left(0,90,180,270\right.$ e $\left.360 \mathrm{mg} \mathrm{dm}^{-3}\right)$, com quatro repetições. Realizaram-se três cortes da parte aérea a cada 30 dias. Foram avaliados o índice de clorofila, a massa seca da parte aérea e das raízes, a concentração de nitrogênio e de potássio, nas folhas. A massa seca da parte aérea apresentou interação entre o nitrogênio e o potássio nos três cortes sendo que no segundo e no terceiro apresentou máxima produção nas doses de nitrogênio e potássio, de 254 e $158 \mathrm{mg} \mathrm{dm}^{-3}$ no segundo e de 250 e $306 \mathrm{mg}$ $\mathrm{dm}^{-3}$ no terceiro, respectivamente. As doses de nitrogênio e de potássio apresentaram interação significativa para a massa seca da parte aérea do capim piatã, nos três cortes. As concentrações de nitrogênio e potássio são influenciadas em função da adubação nitrogenada e potássica isolada por fator. A relação de nitrogênio e potássio no capim piatã é de 1:1.
\end{abstract}




\section{INTRODUCTION}

The Brazilian livestock is characterized mainly by production systems in pastures, for being the least expensive form of food for cattle. Nonetheless, most ranchers do not take advantage of all the potential of these systems (Vitor et al., 2009).

In Cerrado regions, the low natural soil fertility favors the degradation, restricting plant development by high acidity, toxic levels of aluminum and little capacity to supply nutrients. Therefore, for the farmer to maintain a high animal stocking rate, it is necessary to use lime and fertilizer in the establishment and maintenance of pastures (Peron \& Evangelista, 2004).

The nitrogen and potassium fertilization is highlighted as essential for being the two mineral nutrients most absorbed by plants. The interaction between nitrogen and potassium is generally positive, for being of the non-competitive type, in addition to the fact that the stimulation of growth caused by one can lead to deficiency of the other due to nutrient dilution effect (Cantarella, 2007).

Another determining factor in the production of pasture is the choice of grass. Among the new alternatives, Brachiaria brizantha cv. BRS Piatã stands out, due to its high growth rate, good regrowth and high availability of leaves for grazing (Epifanio et al., 2014) However, there is little research about its mineral nutrition.

In this context, this experiment aimed to evaluate the interaction of nitrogen and potassium fertilization for productive and nutritional characteristics of Brachiaria brizantha cv. BRS Piatã grown in Oxisol of the Cerrado.

\section{Material ANd Methods}

The experiment was conducted in a greenhouse at the Federal University of Mato Grosso, Rondonópolis-MT, located at $16^{\circ} 27^{\prime} 50.16^{\prime \prime}$ S latitude and 50 $34^{\prime} 49.56^{\prime \prime}$ W longitude, with an altitude of $284 \mathrm{~m}$, from March to June 2014.

The experimental unit consisted of a pot with $5 \mathrm{dm}^{3}$ of soil. The treatments were distributed in a completely randomized design, with five nitrogen doses $(0 ; 100 ; 200 ; 300$ and $400 \mathrm{mg}$ $\mathrm{dm}^{-3}$ of N) and five potassium doses $(0 ; 90 ; 180 ; 270$ and 360 $\mathrm{mg} \mathrm{dm}{ }^{-3}$ of $\mathrm{K}_{2} \mathrm{O}$ ), combined in a $5 \times 5$ factorial design, with four replicates. The nitrogen and potassium sources were urea and potassium chloride, respectively.

The soil was collected at the depth of $0-0.20 \mathrm{~m}$ in a Oxisol, in an area under Cerrado vegetation, with the following chemical and physical characteristics: $\mathrm{pH}\left(\mathrm{CaCl}_{2}\right): 4.2 ; \mathrm{P}: 1.1 \mathrm{mg} \mathrm{dm}^{-3}$; $\mathrm{K}: 29 \mathrm{mg} \mathrm{dm}^{-3}$; Ca: $0.6 \mathrm{cmol}_{\mathrm{c}} \mathrm{dm}^{-3} ; \mathrm{Mg} 0.3 \mathrm{cmol}_{\mathrm{c}} \mathrm{dm}^{-3}$; Al: 0.5 $\mathrm{cmol}_{\mathrm{c}} \mathrm{dm}^{-3} ; \mathrm{H}: 5.7 \mathrm{cmol}_{\mathrm{c}} \mathrm{dm}^{-3} ; \mathrm{V}: 13.5 \%$; O.M: $28.7 \mathrm{~g} \mathrm{dm}^{-3}$; sand: $549 \mathrm{~g} \mathrm{~kg}^{-1}$; silt: $84 \mathrm{~g} \mathrm{~kg}^{-1}$; clay: $367 \mathrm{~g} \mathrm{~kg}^{-1}$.

Base saturation was increased to $45 \%$ and the soil was incubated with dolomitic limestone (RNV 80.3\%) for 30 days with soil moisture at $60 \%$ of the maximum capacity of water retention. Phosphorus fertilization $\left(\mathrm{P}_{2} \mathrm{O}_{5}\right)$ was held at a rate of $280 \mathrm{mg} \mathrm{dm}^{-3}$, using superphosphate as source.

The nitrogen and potassium fertilizations were divided into three applications, one third at sowing and the other two thirds at intervals of seven days, according to the proposed rates. After each cutting of plants, fertilization maintenance was carried out with nitrogen and potassium in their respective treatments, divided three times at intervals of seven days.

The forage species used was Brachiaria brizantha cv. BRS Piatã, at the sowing depth of $5 \mathrm{~cm}$. Thinning was carried out four days after emergence, leaving five plants per pot. Soil moisture was maintained at $80 \%$ of the maximum capacity of water retention, using the gravimetric method (Bonfim-Silva et al., 2011).

Three cuts were carried out in the shoots at regular intervals of 30 days, with the first two cuts held at $5 \mathrm{~cm}$ from the base of the plants and the third and final cut held close to the base of the plants (Bonfim-Silva et al., 2007). The collected material (shoot and root) was dried in a forced-air circulation oven at $65^{\circ} \mathrm{C}$ until constant mass.

In each cut, the following variables were evaluated: dry mass of shoots, chlorophyll index and the contents of nitrogen and potassium in the diagnostic leaves (Bonfim-Silva \& Monteiro, 2010). The chlorophyll index was measured by SPAD index (Soil Plant Analysis Development), with a portable chlorophyll meter (SPAD - Minolta ${ }^{\circ}$. The determination of nitrogen and potassium content in the diagnostic leaves was performed according to the methodology described by Malavolta et al. (1997).

In the third cut, the roots were evaluated, which were collected and washed with running water using a set of sieves with mesh of 1.00 and $0.25 \mathrm{~mm}$, for later determination of dry mass of roots.

The collected data were submitted to statistical analyses using the Statistical Analysis System (SAS, 2014). Analysis of variance was held for the combinations of nitrogen and potassium rates to study regression at 0.05 probability level. In cases where the interaction of rates was significant, the response surface methodology was used. In cases of no significant interaction between rates, polynomial regression studies of the isolated effects of these two nutrients were performed.

\section{Results AND Discussion}

In the analysis of variance, it was observed significance for the interaction of nitrogen and potassium fertilizer for dry mass production of the shoots of Piatã grass plants in the first, second and third cuts (Figures $1 \mathrm{~A}, \mathrm{~B}$ and $\mathrm{C}$ ).

In the first cut, there was fit to the quadratic regression model for nitrogen; notwithstanding, it was not possible to determine the rate of highest production due to the linear regression fit of potassium, which had growing behavior, with an increase of $63.85 \%$, when the combination of higher rates of nitrogen and potassium was compared with the absence of fertilization with these nutrients (Figure 1A).

In the second and third cuts, both factors fitted to the quadratic regression model, with maximum shoot dry mass production of 18.8 and $20.9 \mathrm{~g} \mathrm{pot}^{-1}$, respectively, obtained at nitrogen and potassium rates of 254 and $158 \mathrm{mg} \mathrm{dm}^{-3}$ for the second cut (Figure $1 \mathrm{~B}$ ), and 250 and $306 \mathrm{mg} \mathrm{dm}^{-3}$ in the third cut (Figure 1C). 
A.

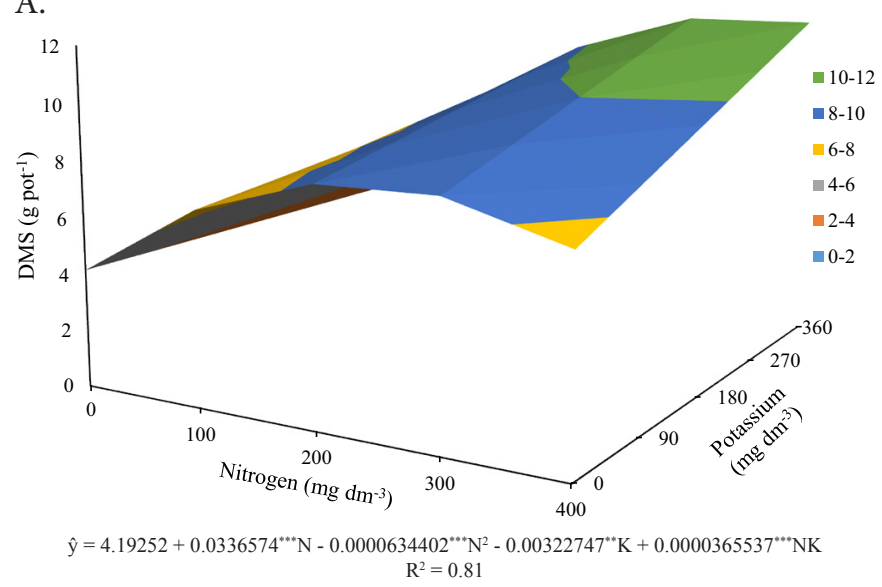

B.

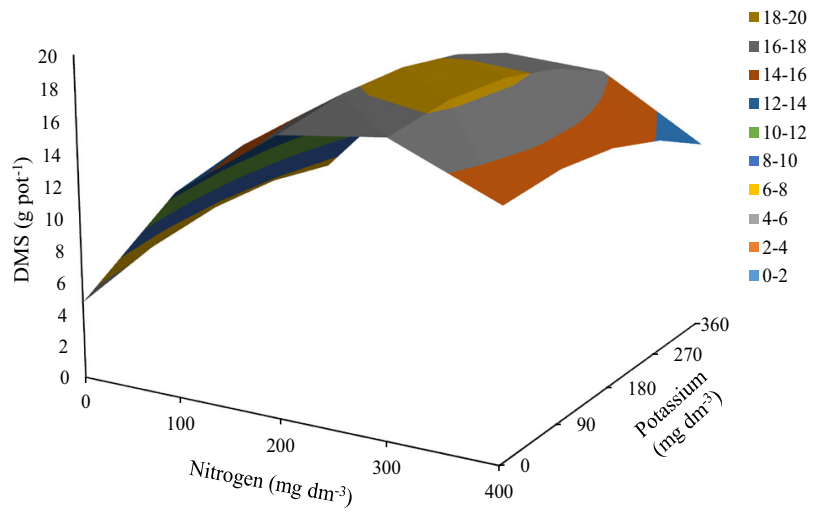

$\hat{\mathrm{y}}=4.79554+0.0957624^{\cdots * *} \mathrm{~N}-0.00017775^{* * *} \mathrm{~N}^{2}+0.02274^{* *} \mathrm{~K}-0.0000442325^{* * *} \mathrm{~K}^{2}-0.0000344306^{* *} \mathrm{NK}$ C.

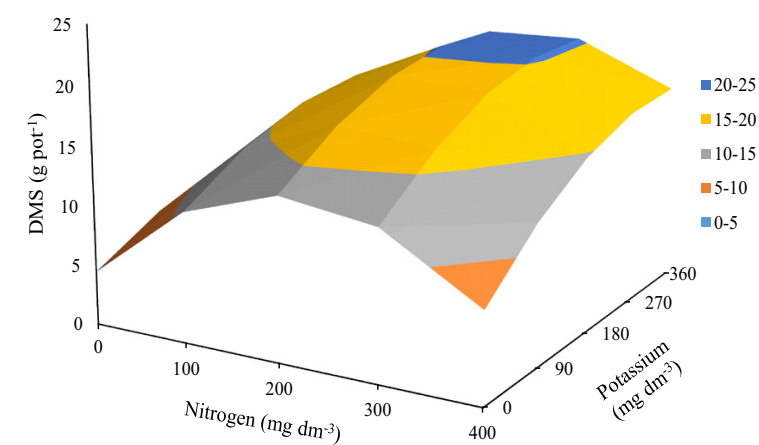

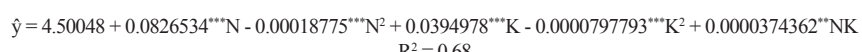
$\mathrm{R}^{2}=0.68$

**, *** Significant at 0.01 and 0.001 probability levels, respectively

Figure 1. Dry mass of shoots (DMS) in the first cut (A), second cut (B) and third cut (C) of Brachiaria brizantha CV. BRS Piatã, as a function of nitrogen and potassium fertilization in Oxisol

It is observed that the nitrogen doses in the second and third cuts remained close to $250 \mathrm{mg} \mathrm{dm}^{-3}$, while potassium rates for the highest production increased from the second $(158 \mathrm{mg}$ $\left.\mathrm{dm}^{-3} \mathrm{~K}_{2} \mathrm{O}\right)$ to the third cut $\left(306 \mathrm{mg} \mathrm{dm}^{-3} \mathrm{~K}_{2} \mathrm{O}\right.$ ), obtaining $\mathrm{N}: \mathrm{K}$ ratios of 1.6:1 and 1:1, respectively.

Confronting the works of Rodrigues et al. (2008), Teles et al. (2011) and Sales et al. (2013) showed that the Brachiaria brizantha cultivars have different behavior regarding the management of fertilization, being important to consider the peculiarities of each cultivar in its management.

The positive increase in the production of foragers due to the increase in nitrogen and potassium doses was observed by several authors, such as Mistura et al. (2006), working with Elephant grass (Pennisetum purpureum Schum.), and Lavres Júnior \& Monteiro (2002) and Rodrigues et al. (2008), researching the Xaraés grass (Brachiaria brizantha).

The interaction between nitrogen and potassium for increased production is due to the potassium function of enzymatic activation of the photosynthesis processes and action in the synthesis of proteins, functions related to nitrogen, for being a basic constituent of the chlorophyll and amino acids (Taiz \& Zeiger, 2013). Therefore, potassium improves the efficiency of nitrogen functions, justifying the increased production of Piatã grass due to the increasing fertilization of both nutrients.

In the response surface study $\left(\hat{y}=5.21273+0.11188^{* * *} \mathrm{~N}\right.$ $-0.000213719^{* * *} \mathrm{~N}^{2}+0.110765^{* * *} \mathrm{~K}-0.000225532^{* * *} \mathrm{~K}^{2} ; \mathrm{R}^{2}$ $=0.50$ ), it is observed that the maximum root production occurred when nitrogen and potassium were supplied at rates of 262 and $246 \mathrm{mg} \mathrm{dm}^{-3}$, respectively, promoting the highest yield of roots $\left(33.45 \mathrm{~g} \mathrm{pot}^{-1}\right)$, and the ratio of nitrogen and potassium that resulted in increased root production was around 1:1 (Figure 1D). The results of Batista \& Monteiro (2006) showed the beneficial effect of nitrogen fertilization on the development of the root system of Marandu grass, due to the increased availability of nutrients.

The roots are fundamental organs for plant development, for supporting the plant and absorbing the water and mineral nutrients from the soil, so the proper development of the root system promotes increased forage production and provides greater tolerance for plants to environmental adversities (Taiz \& Zeiger, 2013).

The chlorophyll index showed significant interaction between nitrogen and potassium for the first cut evaluation; however, for potassium fertilization, it fitted to the linear regression model with increasing behavior, and an increase of $24.25 \%$ of the content when the combination of higher rates of nutrients was compared with the control (Figure 2A).

In the second cut, through the response surface methodology, it was observed the highest chlorophyll index at the nitrogen dose of $300 \mathrm{mg} \mathrm{dm}^{-3}$, while potassium was outside the experimental interval (Figure 2B).

In the third cut, the highest chlorophyll index (51.33) was obtained at the nitrogen and potassium rates of 301 and 236 $\mathrm{mg} \mathrm{dm}{ }^{-3}$, obtaining a $\mathrm{N}: \mathrm{K}$ ratio of 1.3:1 (Figure $2 \mathrm{C}$ ).

The determination of chlorophyll by the chlorophyll meter is a non-destructive method able to predict forage production, which is directly related to the carbon assimilation efficiency, carried out by the photosynthesis process, and their light reactions are initiated by the chlorophyll (Taiz \& Zeiger, 2013).

The nitrogen content in the leaves of Piatã grass showed isolated significant differences for nitrogen fertilization in the first cut, with fit to the quadratic regression model, obtaining the maximum content of $35 \mathrm{~g} \mathrm{~kg}^{-1}$ at the nitrogen dose of 311 $\mathrm{mg} \mathrm{dm}{ }^{-3}$, increasing by $56.5 \%$ the nitrogen content when the rate that provided greater content was compared with the absence of nitrogen fertilization (Figure 3A).

In the second cut, the nitrogen content in the leaves had significant effect for the interaction of nitrogen and potassium rates, with maximum content at the nitrogen rate of $242 \mathrm{mg}$ 


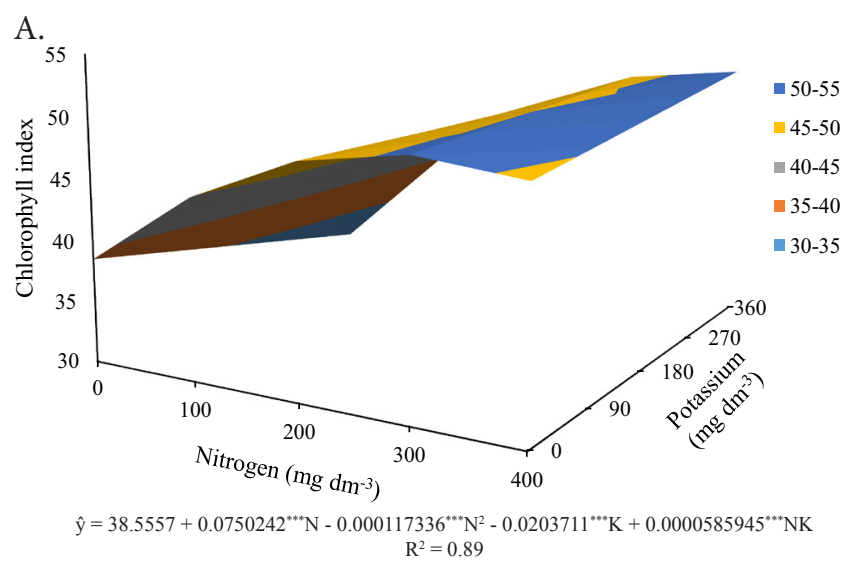

B.
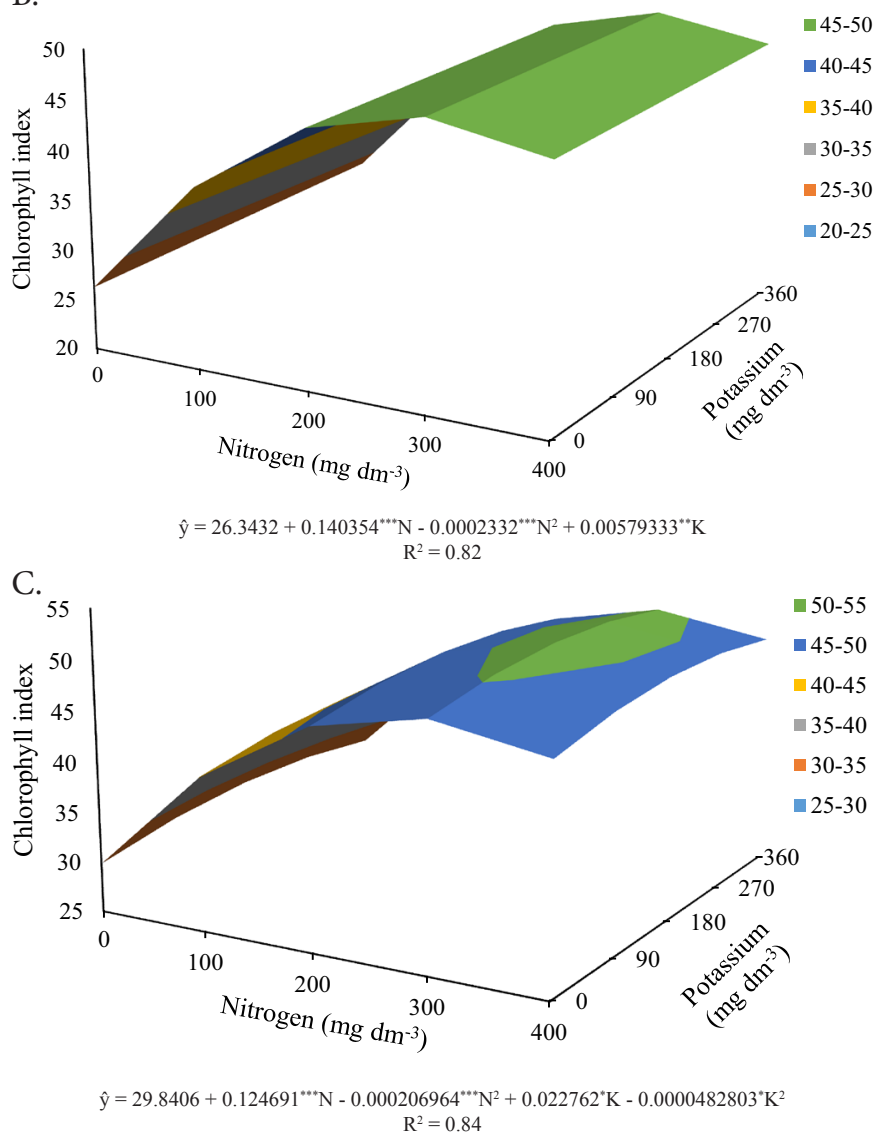

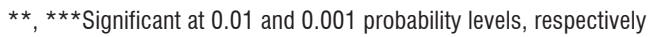

Figure 2. Chlorophyll index in the first cut (A), second cut (B) and third cut (C) of Brachiaria brizantha cv. BRS Piatã, as a function of nitrogen and potassium fertilization in Oxisol

$\mathrm{dm}^{-3}$; notwithstanding, potassium showed the lowest content at a rate of $321 \mathrm{mg} \mathrm{dm}^{-3}$ (Figure $3 \mathrm{~B}$ ).

In the third cut, the nitrogen content isolated showed significant difference for nitrogen fertilization, with fit to the linear regression model, and an increase of $72.3 \%$ in nitrogen content in the leaves of the forage, when the higher rate was compared with the absence of nitrogen in fertilization (Figure 3C).

In the third and final cuts, the content was shown to be increasing based on nitrogen fertilization, suggesting that the continuous renewal of plants leads to a greater demand of nitrogen in physiological functions due to lower dry mass production of the shoots of plants at higher rates of nitrogen.

The potassium fertilization interacted inversely to the nitrogen fertilization regarding the nitrogen content, a fact
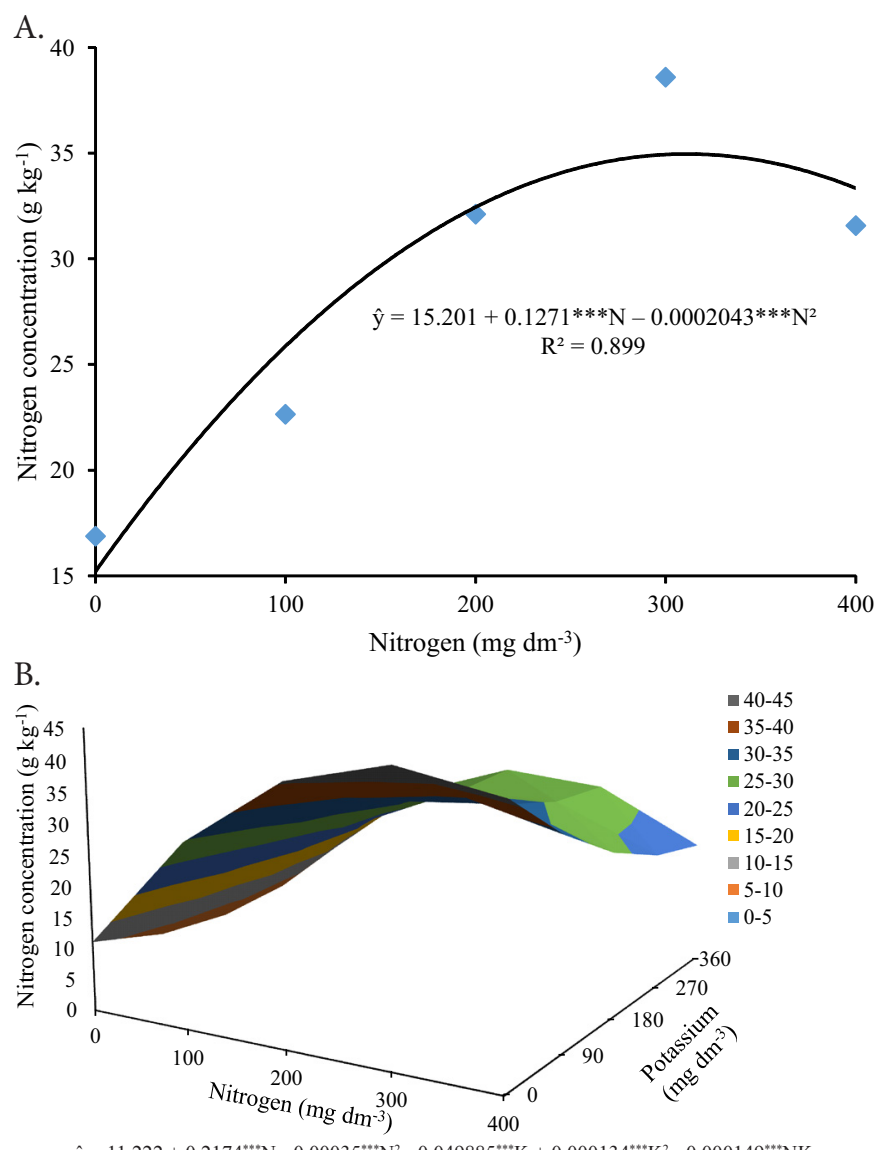

$\hat{y}=11.222+0.2174^{* * *+} \mathrm{N}-0.00035^{\circ * *} \mathrm{~N}^{2}-0.049885^{* * * *} \mathrm{~K}+0.000134^{* * *+} \mathrm{K}^{2}-0.000149^{* * *} \mathrm{NK}$

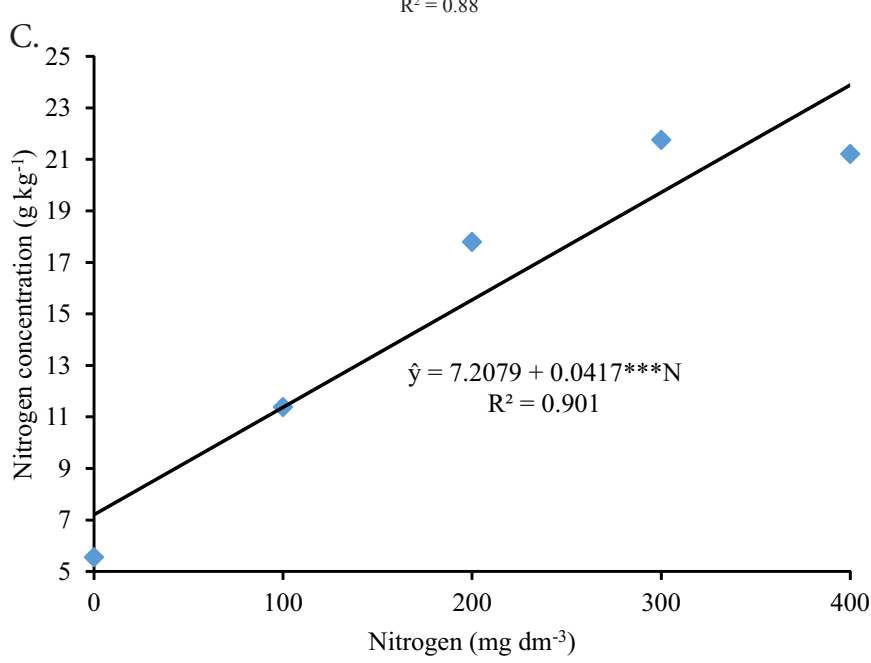

*** Significant at 0.001 probability level

Figure 3. Nitrogen content in diagnostic leaves in the first cut $(A)$, second cut $(B)$ and third cut $(C)$ of Brachiaria brizantha $\mathrm{cV}$. BRS Piatã, as a function of nitrogen and potassium fertilization in Oxisol

that, according to Cantarella (2007), is caused by the nitrogen dilution effect due to the greater shoot mass production with increasing potassium fertilization.

Another factor is that potassium is responsible for enzyme activation, photosynthesis, translocation of assimilates and protein synthesis (Andrade et al., 2003), resulting in reduced efficiency in the use of nitrogen in the plant, justifying the higher content of nitrogen in plants with absence of nitrogen fertilization.

The maximum content of leaf nitrogen found by Lavres Júnior \& Monteiro (2002) in Mombaça grass (Panicum 
A.
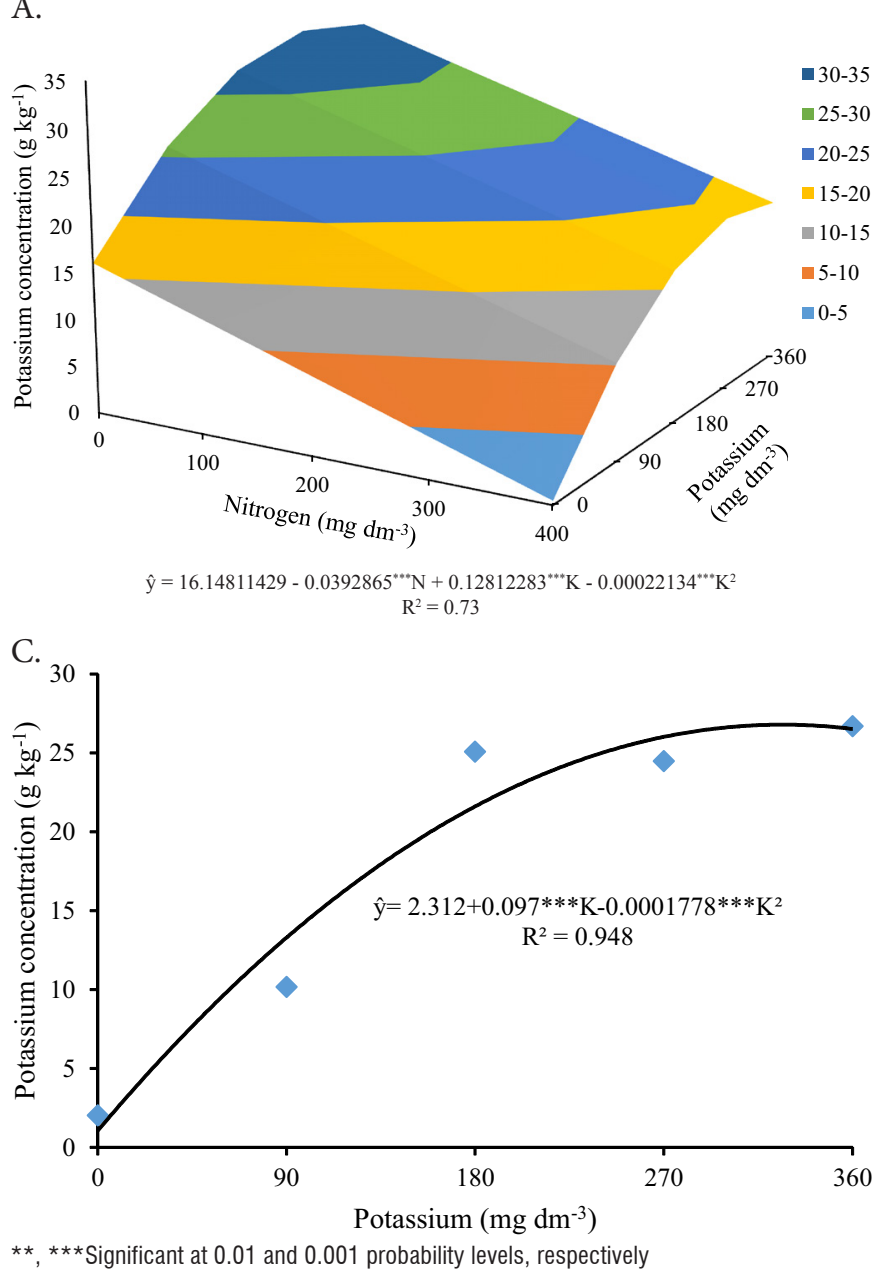

B.

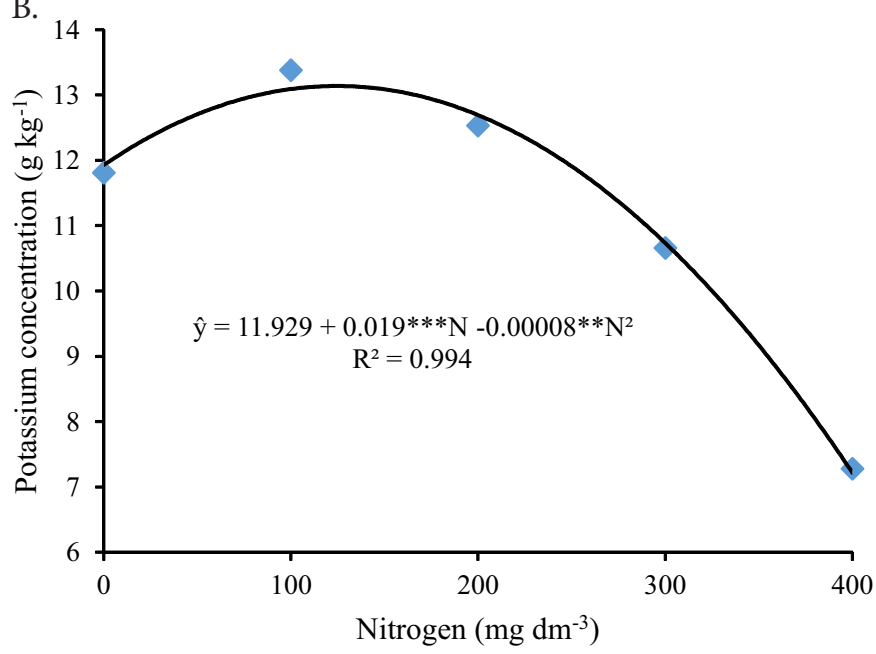

D.

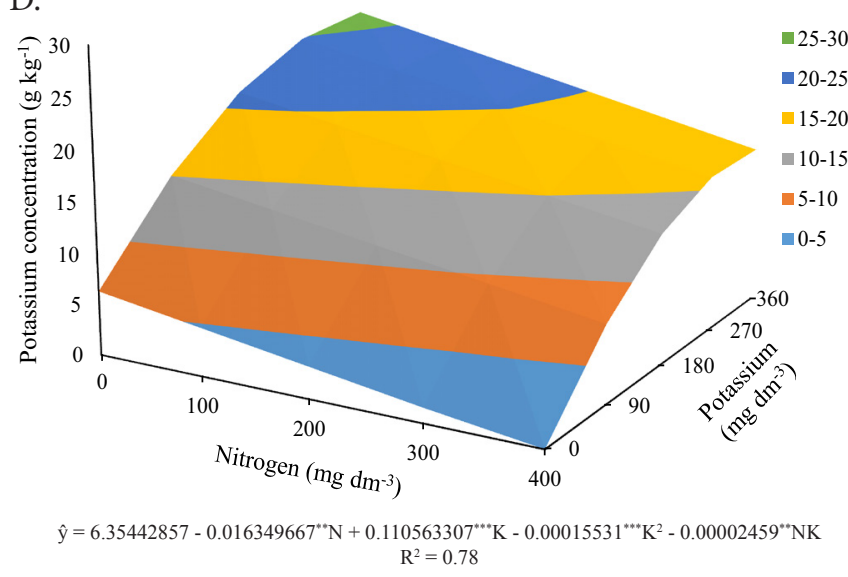

Figure 4. Potassium content in diagnostic leaves in the first cut (A), second cut (B e C), third cut (D) of Brachiaria brizantha cv. BRS Piatã, as a function of nitrogen and potassium fertilization in Oxisol

maximum) was $15.03 \mathrm{~g} \mathrm{~kg}^{-1}$, while Primavesi et al. (2006), working with Marandu grass (Brachiaria brizantha), found nitrogen contents ranging from 17 to $24 \mathrm{~g} \mathrm{~kg}^{-1}$. Nevertheless, for Piatã grass, in the present study, it was found content of up to $34 \mathrm{~g} \mathrm{~kg}^{-1}$ in the first cut, showing a higher nutritional potential, when the nitrogen fertilization is handled properly.

As for the potassium contents in the leaves, there was interaction among the factors only in the third cut, while the first and second Piatã grass cuts showed isolated significant differences for nitrogen and potassium fertilization.

In the first cut for the response surface study, nitrogen rates remained outside the experimental range, with decreasing behavior; as for potassium fertilization, it fitted to the quadratic regression model and the potassium rate of $289 \mathrm{mg} \mathrm{dm}^{-3}$ was responsible for the maximum content of potassium (34.7 $\mathrm{g}$ $\mathrm{kg}^{-1}$ ) (Figure 4A).

In the second cut, there was isolated significant effect of nitrogen and potassium rates, following quadratic regression model for both (Figure $4 \mathrm{~B}$ and $4 \mathrm{C}$ ). The nitrogen dose of $118.75 \mathrm{mg} \mathrm{dm}^{-3}$ promoted the highest content of potassium ( $13.05 \mathrm{~g} \mathrm{~kg}^{-1}$ ), increasing by $11.63 \%$ in relation to the absence of fertilization (Figure 4B).

With respect to potassium fertilizer, the maximum content of $15.5 \mathrm{~g} \mathrm{~kg}^{-1}$ was obtained at a potassium dose of $272 \mathrm{mg}$ $\mathrm{dm}^{-3}$ (Figure $4 \mathrm{C}$ ). The dose of highest content supplied by the potassium fertilizer increased by $85.12 \%$ in relation to the absence of fertilization with this nutrient.
In the third cut, there was no significant interaction between nitrogen and potassium rates. There was an opposite behavior between the two nutrients, and increasing nitrogen doses reduced the content of potassium in the leaves (Figure 4D).

The decrease in potassium content in the leaves of Piatã grass plants as a function of the levels of nitrogen occurs in the plants, according to Cantarella (2007), due to the dilution effect of the content, because of the lower dry mass yield in the absence of nitrogen fertilization.

Fertilizing the Xaraés grass with nitrogen and potassium, Costa et al. (2008) reported isolated effect of nitrogen and potassium on the leaf content of potassium, confirming the results of the first and second cuts of this study. Primavesi et al. (2006), using a combination of nitrogen and potassium fertilization on Marandu grass observed that potassium contents ranged from 28 to $35 \mathrm{~g} \mathrm{~kg}^{-1}$.

\section{Conclusions}

1. Nitrogen and potassium rates showed a significant interaction for dry mass of shoots of Brachiaria brizantha cv. BRS Piatã in the three cuts.

2. The nitrogen and potassium contents are influenced as a function of nitrogen and potassium fertilization in an isolated manner by factor. 
3. The nitrogen and potassium ratio in the Piatã grass crop was around $1: 1$.

\section{Literature Cited}

Andrade, A. C.; Fonseca, D. M.; Queiroz, D. S.; Salgado, L. T.; Cecon, P. R. Adubação nitrogenada e potássica em capimelefante (Pennisetum purpureum Schum. cv. Napier). Ciência e Agrotecnologia, v.27, p.1643-1651, 2003.

Batista, K.; Monteiro, F. A. Sistema radicular do Capim-Marandu considerando as combinações de doses de nitrogênio e de enxofre. Revista Brasileira de Ciência do Solo, v.30, p.821-828. 2006. http:// dx.doi.org/10.1590/s0100-06832006000500008

Bonfim-Silva, E. M.; Monteiro, F. A. Nitrogênio e enxofre na adubação e em folhas diagnósticas e raízes do capim-braquiária em degradação. Revista Brasileira de Zootecnia, v.39, p.1641-1649, 2010. http://dx.doi.org/10.1590/S1516-35982010000800004

Bonfim-Silva, E. M.; Monteiro, F. A.; Silva, T. J. A. Nitrogênio e enxofre na produção e no uso de água pelo capim-braquiária em degradação. Revista Brasileira de Ciência do Solo, v.31, p.309317, 2007. http://dx.doi.org/10.1590/S0100-06832007000200013

Bonfim-Silva, E. M.; Silva, T. J. A.; Cabral, E. A.; Kroth, B. E.; Rezende, D. Desenvolvimento inicial de gramíneas submetidas ao estresse hídrico. Revista Caatinga, v.24, p.180-186, 2011.

Cantarella, H. Nitrogênio. In: Novais, R. F.; Alvarez V., V. H.; Barros, N. F.; Fontes, R. L. F.; Cantarutti, R. B.; Neves, J. C. L. Fertilidade do solo. Viçosa: Sociedade Brasileira de Ciência do Solo, 2007. Cap. VII, p.375-470.

Costa, K. A. P.; Oliveira, I. P.; Faquin, V.; Figueiredo, F. C.; Rodrigues, C. R.; Nascimento, P. P. Adubação nitrogenada e potássica na concentração de nutrientes do capim-xaraés. Ciência Animal Brasileira, v.9, p.86-92, 2008.

Epifanio, P. S.; Costa, K. A. P.; Severiano, E. C.; Cruvinel, W. S.; Bento, J. C.; Perim, R. C. Fermentative and bromatological characteristics of Piata palisadegrass ensiled with levels of meals from biodiesel industry. Semina: Ciências Agrárias, v.35, p.491-504, 2014. http:// dx.doi.org/10.5433/1679-0359.2014v35n1p491

Lavres Júnior, J.; Monteiro, F. A. Combinações de doses de nitrogênio e potássio para a produção e nutrição do capim-mombaça. Boletim Indústria Animal, v.59, p.101-114, 2002.
Malavolta, E.; Vitti, G. C.; Oliveira, S. A. Avaliação do estado nutricional das plantas: Princípios e aplicações. 2.ed. Piracicaba: Potafos. 1997. 319p.

Mistura, C.; Fagundes J. L.; Fonseca, D. M.; Moreira, L. M.; Vitor, C. M. T.; Nascimento Júnior, D.; Ribeiro Júnior, J. I. Disponibilidade e qualidade do capim-elefante com e sem irrigação adubado com nitrogênio e potássio na estação seca. Revista Brasileira de Zootecnia, v.35, p.372-379, 2006. http://dx.doi.org/10.1590/ S1516-35982006000200006

Peron, A. J.; Evangelista, A. R. Degradação de pastagens em regiões de cerrado. Ciência e Agrotecnologia, v.28, p.655-661, 2004. http:// dx.doi.org/10.1590/S1413-70542004000300023

Primavesi, A. C.; Primavesi, O.; Corrêa, L. A.; Silva, A. G.; Cantarella, H. Nutrientes na fitomassa de capim-marandu em função de fontes e doses de nitrogênio. Ciência e Agrotecnologia, v.30, p.562568, 2006. http://dx.doi.org/10.1590/S1413-70542006000300024

Rodrigues, R. C.; Mourão, G. B.; Brennecke, K.; Luz, P. H.; Herling, V. R. Produção de massa seca, relação folha/colmo e alguns índices de crescimento do Brachiaria brizantha cv. Xaraés cultivado com a combinação de doses de nitrogênio e potássio. Revista Brasileira de Zootecnia, v.37, p.394-400, 2008. http://dx.doi.org/10.1590/ S1516-35982008000300003

Sales, E. C. J.; Reis, S. T. D.; Monção, F. P.; Antunes, A. P. D. S.; Oliveira, E. R. D.; Matos, V. M.; Delvaux, A. D. S. Produção de biomassa de capim-marandu submetido a doses de nitrogênio em dois períodos do ano. Agrarian, v.22, p.486-499, 2013.

SAS Institute. SAS 9.4 Output delivery system: User's guide. Cary: SAS Institute, 2014. 1178p.

Taiz, L.; Zeiger, E. Fisiologia vegetal. 5.ed. Porto Alegre: Artmed, 2013. 918p.

Teles, T. G. R. M.; Carneiro, M. S. S.; Soares, I.; Pereira, E. S.; Souza, P. Z.; Magalhães, J. A. Produção e composição química da Brachiaria brizantha cv. MG-4 sob efeito de adubação com NPK. Acta Scientiarum Animal Sciences, v.33, p.137-143. 2011. http:// dx.doi.org/10.4025/actascianimsci.v33i2.9392

Vitor, C. M. T.; Fonseca, D. M.; Cóser, A. C.; Martins, C. E.; Nascimento Júnior, D.; Ribeiro Júnior, J. I. Produção de matéria seca e valor nutritivo de pastagem capim-elefante sob irrigação e adubação nitrogenada. Revista Brasileira de Zootecnia, v.38, p.435-442, 2009. http://dx.doi.org/10.1590/S1516-35982009000300006 